September - 2020

\title{
Research Trends in Mobile Learning
}

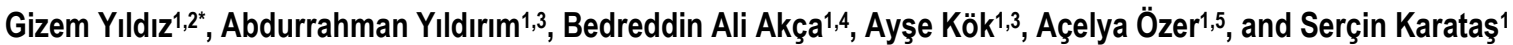
${ }^{1}$ Gazi University, Turkey, ${ }^{2}$ Yüksek Ihtisas University, Turkey, ${ }^{3}$ Ministry of Education, Turkey, ${ }^{4}$ Hitit University, Turkey, ${ }^{5}$ Kırşehir Ahi Evran University, Turkey

*corresponding author

\begin{abstract}
A total of 1023 selected articles published in 2016-2019 related to mobile learning were examined and classified according to the categories in this research: 40\% of these articles used quantitative approaches, $18 \%$ of them used mixed, and $13 \%$ of them were literature reviews. The published studies were analyzed according to research model, sample size, sample level, learning fields, subject-area classification, data collection tool, data analysis technique, dependent variable, independent variable, mobile device, number of authors, and publication year. The findings were analyzed and interpreted as a percentage and frequency. This research will be useful for reviewing current research trends related to mobile learning studies, indicating potential research on the topics, and revealing the needs of the field.
\end{abstract}

Keywords: mobile learning, m-learning, trend analysis, research trends, distance education 


\section{Research Trends in Mobile Learning}

Open and distance learning (ODL) has become indispensable in educational environments because of its flexible learning method, the opportunities it gives students to study at their own pace, independent of time and place, and its evaluation opportunities (Towobola \& Raimi, 2011). ODL in digital environments provides individuals with the opportunity to access course content whenever and wherever they want (Yüksekdağ, 2016). In addition, its collaborative and participatory features offer a learning-centered process. As these digital environments become mobile compatible, mobile devices are also involved in the learning process. The ability to structure information regardless of location and time has made mobile learning (m-learning) a significant learning vision.

Many studies have revealed the effectiveness, efficiency, and superiority of m-learning. These include studies on its use in medicine (Chase et al., 2018; Lin \& Lin, 2016; Nerminathan, Harrison, Phelps, Scott, \& Alexander, 2017); in language learning (Alkhezzi \& Al-Dousari, 2016; Chinnery, 2006; Klímová, 2018); in special education (Judge, Floyd, \& Jeffs, 2015; Karanfiller, Yurtkan, Rüştüoğlu, \& Göksu, 2018); and in the learning of motor skills (Hung, Shwu-Ching Young, \& Lin, 2018); as well as research on the different age groups in different areas and the effects on academic achievement, attitude, motivation, and interaction. These studies have discussed m-learning in different research patterns through variables. By compiling m-learning studies up to the present that have been carried out independently in various cultural environments and depending on emerging technological developments, this study will contribute to the literature by revealing the current situation and determining the research gaps.

\section{Mobile Learning}

Beyond using portable technology and devices in learning environments and focusing on students' mobility, m-learning offers a variety of opportunities to educational theory and practice (Al-Adwan, AlMadadha, \& Zvirzdinaite, 2018). Changes in understanding of access to information, communication, and cooperation have created a new generation of students who can create their own learning context by interacting with each other and their environments in the real and virtual worlds (Al-Adwan et al., 2018). In addition to student roles that can access the information resources they need at any time, question the correctness of the information they reach, produce, and share in collaboration, learn at their own pace and evaluate their own learning. The roles of the teachers that contribute to the motivation of the students, facilitate the process, and are open to learning together with the students are considerable (Özdamlı \& Çavuş, 2011). In the place of predetermined classes with limits and timelines, m-learning community had to redesign learning, embracing the world as its learning environment. Adapting to such developments, which can also be envisaged as life-long learning skills, can remove formal and informal learning limits in the "mobile age" (McQuiggan, Kosturko, McQuiggan, \& Sabourin, 2015). The advantages offered by m-learning, in fact, constitute its distinctive aspects from other distance-education applications.

Students of m-learning create a continuous meaning between location, time, and learning content through mobile devices connected to the wireless network, in accordance with their objectives. The portable feature of mobile personal devices makes them the most attractive way for students to process ideas and information that can be encountered by chance in long-term learning (Sharples, ArnedilloSánchez, Milrad, \& Vavoula, 2009). For example, students learning a language can combine device mobility and the real world, learning the words they do not know through their smartphone applications while roaming the streets (Cohen \& Ezra, 2018). Another feature emphasized in m-learning is that it is 
personalized. With the help of adaptive technologies, the content is presented and updated according to the learning styles and contexts of the students (Song, Wong, \& Looi, 2012). Unlike other distance education applications, mobile devices increase students' sense of ownership (Perry, 2003) and control (Laurillard, 2007). Finally, the feature of being situated means that students interact with real situations and produce meaningful information based on their own experience. Accordingly, concepts can be reformatted as they are used in new situations. In this way, knowledge develops as part of the culture, time, and context (Brown, Collins, \& Duguid, 1989). Students can learn anywhere, anytime using mlearning tools, and they can discuss how their new knowledge can be used in real situations (Huang, Yang, Chiang, \& Su, 2016).

We examined the following studies and created criteria by blending the headings: Hwang and Tsai (2011); Hung and Zhang (2012); Wu et al. (2012); Hwang and Wu (2014); Chee, Yahaya, İbrahim, and Hasan (2017); and Kavaklı and Yakın (2019). Within this framework, we aim to identify trends by examining articles on m-learning published from 2016 to 2019.

This work is important in terms of its contribution of current data to researchers working on m-learning. We analyzed the data on m-learning according to the following criteria: research models, sample sizes, sample levels, learning fields, subject area classifications, data collection tools, data analysis techniques, dependent variables, independent variables, mobile devices, number of authors, and publication years.

\section{Related Research}

The following trend analysis studies are based on different databases, year ranges, and research problems. In this section we have examined these studies in detail.

Hwang and Tsai (2011) examined 154 articles published in six major The Social Sciences Citation Index (SSCI) journals between 2001 and 2010. They analyzed the articles in their study according to the sample group, learning field, and country identity. Their results showed a significant increase in the number of articles in the last 10 years and they observed that higher education students are the most frequently used research sample. Most of the articles did not focus on a specific learning field and investigated students' motivations, perceptions, and attitudes towards learning in all environments, along with orientations to the course (such as computer literacy or other skills necessary to take the course online or for a new subject area) for subject areas such as engineering, languages, arts, and science.

Hung and Zhang (2012) investigated the trends of m-learning in 144 articles published in five journals between 2003 and 2008. In general, they investigated the publication year, publication category, subject area classification, country, university, and journal identities. As a result, more studies were found on effectiveness, assessment, personalized systems, strategies, and frameworks within the scope of mlearning in the studies they examined.

In a study by Wu et al. (2012), the authors discussed 144 articles indexed by SSCI between 2003 and 2010. They analyzed m-learning studies around the number of citations, data collection tools, methods, sample groups, the results of the study, and the variables of mobile devices used. In the studies they examined, the survey was the most used data collection tool and experimental studies showed the majority. Also, most of the studies are focused on system design. The most commonly used tools in the studies were mobile phones and PDA. In addition, the most preferred working group has been primary and university students. Wu et al. (2012) examined the studies according to the number of citations. The most cited articles focused on the design of the m-learning system and the effectiveness of the system. 
Hwang and $\mathrm{Wu}$ (2014) analyzed 214 publications on the use of mobile technologies in educational technologies in seven major SSCI journals published between 2008 and 2012. As a result of these examinations, they stated that m-learning was promising in improving students' learning success, motivation, and interests. In addition, it has been concluded that smartphones and tablets have been adopted as m-learning devices in recent years.

Chee et al. (2017) examined 144 articles published in six journals in the category of training technologies between 2010 and 2015. They analyzed the studies in the scope of research purpose, learning field, sample group, mobile devices, research design, training context (formal/informal), learning outcome (positive, negative, neutral), journal, country, and publisher.

In a content analysis study carried out by Sönmez, Göçmez, Uygun, and Ataizi (2018), the authors examined studies on m-learning conducted between 2013 and 2017. The study, which examined 11 articles published in English only, concluded that quantitative methods are preferred to other methods. In addition, the study reported that researchers focused on the topic of determining learners' views on m-learning more often than other topics.

Kavaklı and Yakın (2019) examined 37 studies on m-learning published in Educational Technology Theory and Practice, Turkish Online Journal of Educational Technology, and Turkish Online Journal of Distance Education between 2015 and 2018 and in the first quarter of 2019. They found that mlearning technologies, attitude, and perception were the most investigated subjects and that the majority of studies used quantitative research methods.

\section{Research Problem and Significance}

In studies similar to this study in the literature, a maximum of 233 studies were analyzed. In this study, we have analyzed many more studies and conducted a more comprehensive analysis. We blended studies and brought together and put forward different variables and analyses.

In the research on m-learning published between 2016 and 2019, we examined the distribution according to the following 10 categories; (1) method; (2) sample size; (3) sample level; (4) learning field; (5) subject area; (6) data collection tool; (7) data analysis technique; (8) dependent variable; (9) independent variable; (10) used mobile devices.

\section{Limitations}

The study was limited in terms of the database used in the selection of the analyzed articles, the year range of the analyzed articles (2016-2019), and the language of the analyzed articles. In addition, the analyzed articles prevent the generalization of the results of this study.

\section{Methodology}

This study, we analyzed articles on m-learning between 2016 and 2019 according to the trend analysis method. We analyzed the data according to this method's descriptive analysis technique. This is a qualitative technique with the aim to present the findings in an organized and interpreted way (Ylldirm \& Şimşek, 2018, p. 239). And we explained descriptions and discussed the cause-effect relationship. 
Through research on m-learning, we found 1046 articles through the SCOPUS database and Google Scholar. We excluded 23 articles that were repeats, conference papers, or in a non-English language, and thus examined 1023 articles. In researching the articles, we used the keywords "mobile learning" and "m-learning." Then, to determine the compatibility of the article, we randomly selected 35 articles by year to be examined and coded. We then created categories and then created an analysis table. We used a Kappa test to determine the compliance rate. The Kappa test measures the reliability of the agreement between categorical examinations by two or more coders (Kllıç, 2015). In our first coding study, the coefficient of fit between us was ".62". Since this value is lower than .75 for Kappa, we came together to convince each other. As a result of the discussions, we revised each other's studies within a week and conducted compliance testing. The compliance testing found a reliability coefficient of .82, thus reaching an ideal coefficient of concordance (Kılıç, 2015). After reaching the sufficient compatibility ratio, 35 articles were reduced from the total number of articles and the remaining " 988 " articles were distributed randomly by years among researchers, who coded them using the relevant categories tables. The codings were then brought together and the following findings were reached.

\section{Findings}

We investigated the research models, sample size, sample level, learning field, subject area classification, data collection tool, data analysis method, dependent and independent variables, and distribution of the studies within the scope of m-learning.

\section{Research Model}

We carried out descriptive analysis by analyzing the studies on m-learning according to their method. The classification in the research method is based on Göktaş, Küçük, Aydemir, Telli, Arpacık, Yıldırım and Reisoğlu (2012). If the feature being analyzed was not included in the classification, the study was defined as "others"; if it was not specified in the article, it was defined as "not specified"; if it was not suitable for classification, it was defined as "not available." These definitions are used in all the tables. The distribution of the studies examined according to method is provided in Table 1.

Table 1

Distribution of Studies by Method

\begin{tabular}{llcc}
\hline \multicolumn{1}{c}{ Model } & \multicolumn{1}{c}{ Research design } & f \\
\hline & Comparative & & \\
& Descriptive & & \\
& Correlational & & \\
& Quasi-experimental & \multirow{2}{*}{39.98} \\
& Survey & & \\
& Weak experimental & & \\
& True experimental & & \\
& Ex post facto & & \\
& Single subject (group) & & \\
& Triangulation & \multirow{2}{*}{188} & \\
Mixed & Explanatory & & \\
& Exploratory &
\end{tabular}




\begin{tabular}{llcc} 
Literature review & $\begin{array}{l}\text { Literature review } \\
\text { Meta-analysis }\end{array}$ & 133 & 13.00 \\
Others & $\begin{array}{l}\text { System development, design-based } \\
\text { research, etc. }\end{array}$ & 128 & 12.51 \\
& $\begin{array}{l}\text { Case study } \\
\text { Grounded theory } \\
\text { Concept analysis } \\
\text { Culture analysis } \\
\text { Phenomenology }\end{array}$ & 116 & 11.34 \\
& & & \\
Not specified & Total & 49 & 4.79 \\
\hline
\end{tabular}

Of the 1023 studies analyzed according to classification, $39.98 \%$ were quantitative, $18.38 \%$ were mixed, and $13 \%$ were literature review studies, including system development and design-based research studies. To summarize, the classification of the studies according to research method is provided in Figure 1.
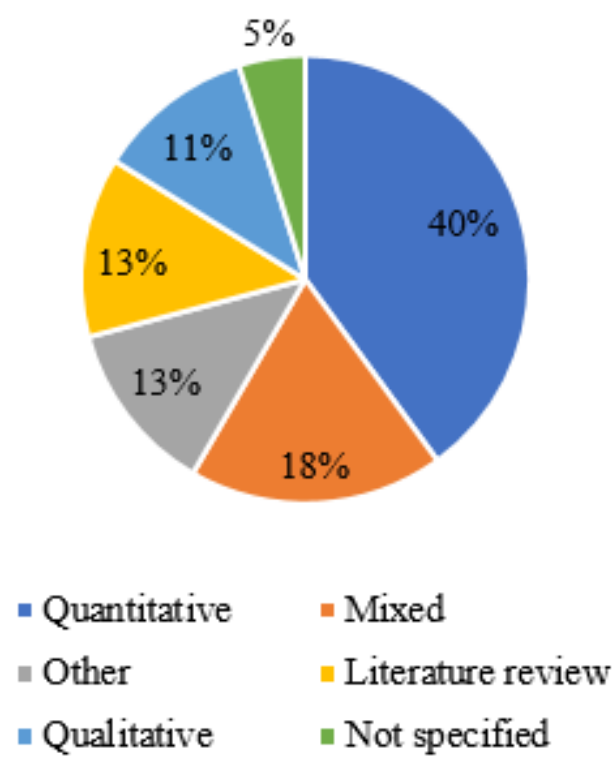

Figure 1. Distribution of studies by method.

An examination of the studies in which quantitative studies are predominant reveals that they use a questionnaire a data collection tool. Quantitative research in m-learning studies have focused on quantitative, mixed, and system development studies.

\section{Sample Size}

We examined the sample sizes of the studies on m-learning and carried out descriptive analysis, using the sample-size classification of Göktaş et al. (2012) as a basis. We updated Table 2 based on the needs of the research. The distribution of studies according to sample size is provided in Table 2. Sample size 
was between 31 and 100 in $27.57 \%$ of the studies, and between 101 and 300 in $20.14 \%$ of the studies. In $17.79 \%$ of the studies, the size could not be determined; these are classified as non-samples. In mlearning studies, the sample size was 31 and above, and studies without sample are more common.

Table 2

Distribution of Studies by Sample Size

\begin{tabular}{lccc}
\hline & Sample size & $\mathrm{f}$ & $\%$ \\
\hline $31-100$ & & 282 & $27 \cdot 57$ \\
$101-300$ & 206 & 20.14 \\
Non-sample study & 182 & 17.79 \\
$301-1000$ & 108 & 10.56 \\
$11-30$ & 112 & 10.95 \\
$1-10$ & & 45 & $4 \cdot 40$ \\
$>=1001$ & 32 & 3.13 \\
Not specified & Total & 56 & 5.47 \\
\hline
\end{tabular}

Adapted from "Educational Technology Research Trends in Turkey: A Content Analysis of the 2000-2009 Decade," by Göktaş et al., 2012, Educational Sciences: Theory and Practice, 12(1), p. 199. Copyright 2012 by the Educational Consultancy and Research Center.

\section{Sample Level}

We carried out descriptive analysis of the sample levels in studies related to m-learning, basing the sample level classification on that of Göktaş et al. (2012). These categories have been taken as the basis of m-learning studies addressing wide ranks. In $42.60 \%$ of the studies, the sample level was higher education; and in $16.41 \%$ of the studies, the sample level was $\mathrm{K}-12$ level. In $20.40 \%$ of the studies, the sample levels were not available. Most m-learning activities are aimed at students with a higher education $(f=449)$. The distribution of the studies according to their sample levels is given in Table 3 .

Table 3

Distribution of Studies by Sample Level

\begin{tabular}{|c|c|c|}
\hline Sample level & $\mathrm{f}$ & $\%$ \\
\hline Higher education & 449 & 42.60 \\
\hline $\mathrm{K}-12$ & 173 & 16.41 \\
\hline Instructor & 96 & 9.11 \\
\hline In-service/Employee & 42 & 3.98 \\
\hline Other & 30 & 2.85 \\
\hline Preschool & 15 & 1.42 \\
\hline Parents & 6 & 0.57 \\
\hline Not available & 215 & 20.40 \\
\hline Not specified & 28 & 2.66 \\
\hline
\end{tabular}

\section{Learning Fields}

We carried out descriptive analysis of m-learning studies related to learning fields, basing our classification of learning fields on OECD (2007). We found that $22.68 \%$ of the studies were in the field of social sciences, $18.18 \%$ in humanities, and $14.37 \%$ in natural sciences. Studies on m-learning are 
mostly carried out in the social sciences. The distribution of the studies by learning fields is given in Table 4 .

Table 4

Distribution of Studies by Learning Fields

\begin{tabular}{|c|c|c|c|}
\hline Discipline & Sub-discipline & $\mathrm{f}$ & $\%$ \\
\hline \multirow{9}{*}{ Social sciences } & Psychology & \multirow{9}{*}{232} & \multirow{9}{*}{22.68} \\
\hline & Economy and business & & \\
\hline & Educational sciences & & \\
\hline & Sociology & & \\
\hline & Law & & \\
\hline & Political science & & \\
\hline & Social and economic geography & & \\
\hline & Media and communication & & \\
\hline & other social sciences & & \\
\hline \multirow{6}{*}{ Humanities } & History and archeology & \multirow{6}{*}{186} & \multirow{6}{*}{18.18} \\
\hline & Language and literature & & \\
\hline & Philosophy, ethics, and religion & & \\
\hline & $\begin{array}{l}\text { Art (art, art history, performing arts, } \\
\text { music) }\end{array}$ & & \\
\hline & Other humanities & & \\
\hline & Mathematics & & \\
\hline \multirow{6}{*}{ Natural sciences } & Computer and information sciences & \multirow{6}{*}{147} & \multirow{5}{*}{$14 \cdot 37$} \\
\hline & Physical sciences & & \\
\hline & Chemistry sciences & & \\
\hline & $\begin{array}{l}\text { World and related environmental } \\
\text { sciences }\end{array}$ & & \\
\hline & Biological sciences & & \\
\hline & Other natural sciences & & \multirow{11}{*}{11.93} \\
\hline \multirow{11}{*}{$\begin{array}{l}\text { Engineering and } \\
\text { technology }\end{array}$} & $\begin{array}{l}\text { Engineering (construction, electrical, } \\
\text { electronics, knowledge) }\end{array}$ & \multirow{11}{*}{122} & \\
\hline & Mechanical & & \\
\hline & Chemical & & \\
\hline & Materials & & \\
\hline & Medical & & \\
\hline & Environment (environmental & & \\
\hline & biotechnology) & & \\
\hline & Industrial biotechnology & & \\
\hline & Nanotechnology & & \\
\hline & Other engineering and technologies & & \\
\hline & Basic medicine & & \\
\hline \multirow{4}{*}{ Medical and health } & Clinical medicine & \multirow{4}{*}{98} & \multirow{4}{*}{9.58} \\
\hline & Health sciences & & \\
\hline & Health biotechnology & & \\
\hline & Other medical sciences & & \\
\hline Others & $\begin{array}{l}\text { A learning field outside the } \\
\text { classification }\end{array}$ & 38 & $3 \cdot 71$ \\
\hline \multirow{4}{*}{ Agricultural sciences } & Agriculture, forestry, and fisheries & \multirow{4}{*}{14} & \multirow{4}{*}{1.37} \\
\hline & Animal and dairy science & & \\
\hline & Veterinary science & & \\
\hline & Agricultural biotechnology & & \\
\hline
\end{tabular}


Not available

Other agricultural sciences

Not specified

Total

103

10.07

83

8.11

1023

100

\section{Subject Area Classification}

We analyzed studies on m-learning according to the subject-area classification of Drysdale, Graham, Spring and Halverson (2013). We updated Table 5 based on the needs of the research. As indicated in Table 5 , the subject area in $32.66 \%$ of the studies was technology, and in $22.67 \%$ of the studies was learner outcomes.

Table 5

Distribution of Studies by Subject Area Classification

\begin{tabular}{|c|c|c|c|}
\hline Domain & Subdomain & $\mathrm{f}$ & $\%$ \\
\hline Technology & $\begin{array}{l}\text { Usage and role; effect; type; } \\
\text { application; and familiarity }\end{array}$ & 340 & 32.66 \\
\hline Learner outcomes & $\begin{array}{l}\text { Independence in performance } \\
\text { outcomes; learner satisfaction; } \\
\text { participation; effectiveness; } \\
\text { motivation and effort; learning; and } \\
\text { retention rates }\end{array}$ & 236 & 22.67 \\
\hline Instructional design & $\begin{array}{l}\text { Models, strategies, and best practices; } \\
\text { design process; implementation; } \\
\text { environment and course structure; } \\
\text { and assessment tools }\end{array}$ & 147 & 14.12 \\
\hline Disposition & $\begin{array}{l}\text { Perceptions; attitudes; preferences; } \\
\text { student expectations; and learning } \\
\text { styles }\end{array}$ & 123 & 11.82 \\
\hline Other & $\begin{array}{l}\text { Benefits and challenges; access and } \\
\text { availability; support system; time } \\
\text { efficiency; the nature and role of } \\
\text { blended learning; and international } \\
\text { issues. }\end{array}$ & 114 & 10.95 \\
\hline Comparison & $\begin{array}{l}\text { Blended and face-to-face; and blended } \\
\text { and online. }\end{array}$ & 38 & 3.65 \\
\hline Interaction & $\begin{array}{l}\text { Learner-instructor; general } \\
\text { interaction; learner-learner; } \\
\text { collaboration; community; and social } \\
\text { being }\end{array}$ & 27 & 2.59 \\
\hline $\begin{array}{l}\text { Professional } \\
\text { development }\end{array}$ & Professional development & 15 & 1.44 \\
\hline Demographics & Learner and instructor & 1 & 0.10 \\
\hline Total & & 1041 & 100 \\
\hline
\end{tabular}

Adapted from “An Analysis of Research Trends in Dissertations and Theses Studying Blended Learning," by Drysdale et al., 2013, The Internet and Higher Education, 17, p. 95. Copyright 2013 by Elesvier. 


\section{Data Collection Tool}

We analyzed the data collection tool in studies on m-learning according to the classification of BeisselDurant (2004). We updated Table 6 based on the needs of the research. As seen in Table 6, 39.69\% of the studies used a survey as a data collection tool.

Table 6

Distribution of Studies by Data Collection Tool

\begin{tabular}{|c|c|c|c|}
\hline Tool & Subcategory & $\mathrm{f}$ & $\%$ \\
\hline Questionnaire & $\begin{array}{l}\text { Question design; self-managed } \\
\text { questionnaire; state survey; questionnaire } \\
\text { design; question types; question statement; } \\
\text { structure of questionnaire; preliminary } \\
\text { questionnaire; Web-based questionnaire }\end{array}$ & 429 & 39.69 \\
\hline Advanced technologies & $\begin{array}{l}\text { Computer-aided data collection; grid } \\
\text { technology; audio and video; data mining; } \\
\text { e-social science approaches to data } \\
\text { collection }\end{array}$ & 134 & 12.40 \\
\hline Interview & $\begin{array}{l}\text { Question design; qualitative and } \\
\text { quantitative; telephone; face-to-face; focus } \\
\text { groups/group, interview; computerized; } \\
\text { standardized and non-standardized; } \\
\text { interview practice; interviewer; interview } \\
\text { procedure; interviewer training; } \\
\text { responders; response records }\end{array}$ & 123 & 11.38 \\
\hline Mixed & $\begin{array}{l}\text { Combinations of two or more data } \\
\text { collection tools }\end{array}$ & 89 & 8.23 \\
\hline Observation & $\begin{array}{l}\text { Field observation; field test; participant } \\
\text { observation; laboratory observation }\end{array}$ & 65 & 6.01 \\
\hline $\begin{array}{l}\text { Self-administrative } \\
\text { non-specified } \\
\text { questioning }\end{array}$ & $\begin{array}{l}\text { Question design; mail survey; e-mail } \\
\text { survey; Web-based questionnaire; public } \\
\text { opinion polls }\end{array}$ & 32 & 2.96 \\
\hline Sample & $\begin{array}{l}\text { Sample and survey designs; sample types } \\
\text { (cluster sample; multiphase sample; etc.) }\end{array}$ & 22 & 2.04 \\
\hline $\begin{array}{l}\text { Use of administrative } \\
\text { resources }\end{array}$ & & 18 & 1.67 \\
\hline Measurement & $\begin{array}{l}\text { Measurement of attitude; behavior; ability; } \\
\text { etc. }\end{array}$ & 17 & 1.57 \\
\hline Visual methods & & 1 & 0.09 \\
\hline \multirow[t]{2}{*}{ Not available } & & 116 & 10.73 \\
\hline & & 35 & 3.24 \\
\hline
\end{tabular}

Adapted from “A Typology of Research Methods Within the Social Sciences,” by Beissel-Durant, 2004, NCRM Working Paper. (http://eprints.ncrm.ac.uk/115/1/NCRMResearchMethodsTypology.pdf). In the public domain. 


\section{Data Analysis Technique}

We examined data analysis techniques used in m-learning studies according to the classification of Karataş, Ozcan, Polat, Yilmaz, and Topuz (2014). We updated Table 7 based on the needs of the research. As Table 7 shows, after analyzing the distribution of studies according to data analysis techniques, we found that $22.28 \%$ of the studies used a descriptive technique.

Table 7

Distribution of Studies According to Data Analysis Technique

\begin{tabular}{|c|c|c|}
\hline Technique & $f$ & $\%$ \\
\hline Descriptive & 281 & 22.28 \\
\hline t-Test & 154 & 12.21 \\
\hline Content analysis & 149 & 11.82 \\
\hline (M)ANOVA & 112 & 8.88 \\
\hline Correlation & 77 & 6.11 \\
\hline Other & 53 & 4.20 \\
\hline Structural equation model & 52 & 4.12 \\
\hline (M)ANCOVA & 43 & 3.41 \\
\hline Chi-Square & 30 & 2.38 \\
\hline Multiple regression & 35 & 2.78 \\
\hline Factor analysis & 22 & 1.74 \\
\hline z-Test & 16 & 1.27 \\
\hline Not available & 140 & 11.10 \\
\hline Not specified & 97 & 7.69 \\
\hline Total & 1261 & 100 \\
\hline
\end{tabular}

Adapted from "Trends in Distance Education: Theories and Methods," by Karataş et al., in , T.V. Yuzer and G. Eby (Eds.), Handbook of research on emerging priorities and trends in distance education: Communication, pedagogy, and technology (p. 141), 2014, Hershey, PA: Information Science Reference; IGI Global . Copyright 2014 by IGI Global.

\section{Dependent Variable}

Descriptive analysis was carried out to determine (1) whether the studies covered within the scope of mlearning research include dependent variables and (2) the distribution of dependent variables frequently used in the studies. The classification of dependent variables is based on Karataş, Yılmaz, Dikmen, Ermiş, and Gürbüz (2017). We updated Table 8 based on the needs of the research.

As shown in Table 8, the most studied dependent variable was learning outcomes (20.24\%). This was followed by studies categorized as not available (19.68\%). Similarly, a high frequency rate was obtained from studies categorized as not specified (15.02\%). The results of the analysis on the dependent variable are presented in Table 8. 
Table 8

Distribution of Studies According to Dependent Variable

\begin{tabular}{|c|c|c|}
\hline Dependent variable & $\mathrm{f}$ & $\%$ \\
\hline Learning outcomes & 252 & 20.24 \\
\hline Attitude & 105 & 8.43 \\
\hline Motivation & 65 & 5.22 \\
\hline Availability & 60 & 4.82 \\
\hline Satisfaction & 45 & 3.61 \\
\hline Students' views & 41 & 3.29 \\
\hline Efficiency & 28 & 2.25 \\
\hline Participants' views & 23 & 1.85 \\
\hline Participation & 19 & 1.53 \\
\hline Interaction & 19 & 1.53 \\
\hline Cooperation & 13 & 1.04 \\
\hline Instructor's performance & 7 & 0.56 \\
\hline Readiness & 5 & 0.40 \\
\hline Communication & 4 & 0.32 \\
\hline Social readiness & 3 & 0.24 \\
\hline Other & 124 & 9.96 \\
\hline Not available & 245 & 19.68 \\
\hline Not specified & 187 & 15.02 \\
\hline Total & 1245 & 100 \\
\hline
\end{tabular}

Adapted from "Interaction in Distance Education Environments" by Karataş et al., 2017, Quarterly Review of Distance Education, 18(1), p. 63. Copyright 2017 by Information Age Publishing Inc.

\section{Independent Variable}

We carried out descriptive analysis to reveal (1) whether the studies within the scope of m-learning research included independent variables and (2) the distribution of independent variables frequently used in the studies. The classification of independent variables is based on that of Karataş et al. (2017). We updated Table 9 based on the needs of the research.

As shown in Table 9, the most studied independent variable was the impact of the learning environment on dependent variables (35.71\%). This was followed by the variable of gender (2.31\%). This was followed by studies categorized as not available (24.54\%). Similarly, a high frequency rate was obtained from studies categorized as not specified (18.09\%) and other (7.60\%). In addition, we found no studies analyzing the country variable in the data source used to classify the independent variables. The results of the analysis on the independent variable are presented in Table 9. 
Table 9

Distribution of Studies by Independent Variable

\begin{tabular}{|c|c|c|}
\hline Independent variable & $\mathrm{f}$ & $\%$ \\
\hline Learning environment & 371 & 35.71 \\
\hline Gender & 24 & 2.31 \\
\hline Availability & 21 & 2.02 \\
\hline Participants' views & 21 & 2.02 \\
\hline Experience & 17 & 1.64 \\
\hline Training method & 13 & 1.25 \\
\hline Age & 11 & 1.06 \\
\hline Class level & 10 & 0.96 \\
\hline Satisfaction & 9 & 0.87 \\
\hline Interaction & 9 & 0.87 \\
\hline Participation & 8 & 0.77 \\
\hline Academic achievement & 3 & 0.29 \\
\hline Other & 79 & 7.60 \\
\hline Not available & 255 & 24.54 \\
\hline Not specified & 188 & 18.09 \\
\hline Total & 1039 & 100 \\
\hline
\end{tabular}

Adapted from "Interaction in Distance Education Environments" by Karataş et al., 2017, Quarterly Review of Distance Education, 18(1), p. 63. Copyright 2017 by Information Age Publishing Inc.

\section{Use of Mobile Devices}

We undertook a descriptive analysis to determine (1) whether the studies within the scope of m-learning research included any mobile devices and (2) the distribution of mobile devices frequently used in the studies. Mobile device classification was based on that of Chee et al. (2017). Table 10 indicates the distribution findings of mobile devices in primary studies. We updated Table 10 based on the needs of the research.

Table 10 shows that mobile phones were the most used mobile device (37.27\%). Ordinary mobile phones (which have no smart features) showed up in a limited number of studies. We also included these devices in the mobile phone category. While the tablet (18.25\%) was the second most widely used mobile device, we observed that studies that did not use any mobile device (evaluated in the category of not available) were in the majority (18.68\%). The number of studies that do not specify the mobile device in their research reports is also high (17.38\%). PDAs (0.87\%) have been the least frequently used mobile devices in the investigated studies. 
Table 10

Distribution of Studies by Mobile Devices

\begin{tabular}{|c|c|c|}
\hline Device & $\mathrm{f}$ & $\%$ \\
\hline Mobile phone & 429 & 37.27 \\
\hline Tablet & 210 & 18.25 \\
\hline Other mobile devices & 87 & 7.56 \\
\hline Personal digital assistants & 10 & 0.87 \\
\hline Not available & 215 & 18.68 \\
\hline Not specified & 200 & 17.38 \\
\hline Total & 1151 & 100 \\
\hline
\end{tabular}

Adapted from "Review of Mobile Learning Trends 2010-2015: A Meta-Analysis," by Chee et al., 2017, Journal of Educational Technology \& Society, 2O(2), p. 121. Copyright 2017 by International Forum of Educational Technology and Society.

\section{Number of Authors}

The grouping of the articles according to the number of authors is given in Figure 2. Figure 2 shows that $21 \%$ of the articles were single author, $29 \%$ had two authors, and $50 \%$ had three or more authors.

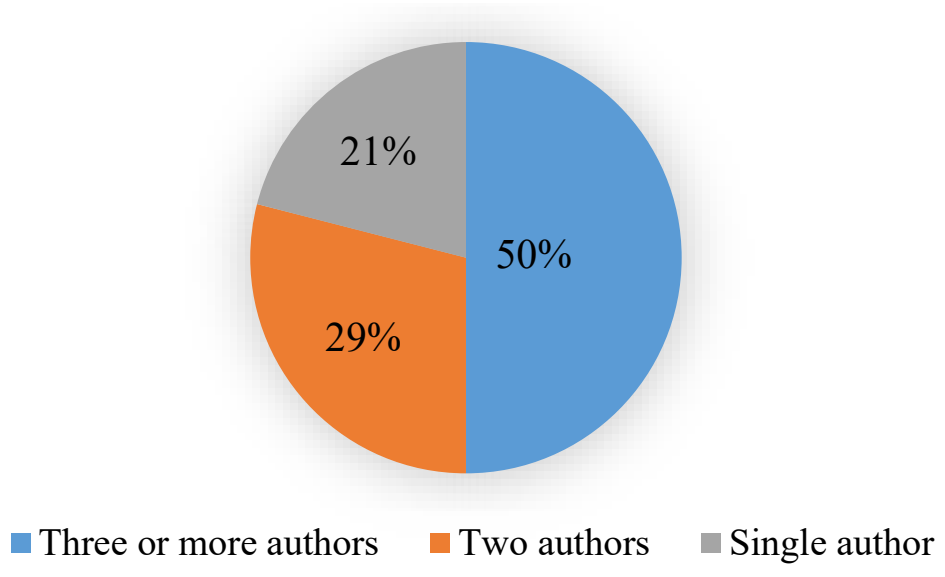

Figure 2. Distribution of studies by number of authors.

\section{Year of Publication}

The chart in Figure 3 groups the articles according to the publication year. It shows that the rate of studies conducted in 2016 was $22.48 \%(f=230)$, the rate of studies conducted in 2017 was $21.40 \%(f=$ 219), the rate of studies conducted in 2018 was $25.21 \%(f=258)$, and the rate of studies conducted in 2019 was $30.88 \%(f=316)$. In 2019, a slight increase was observed in the number of researches. 


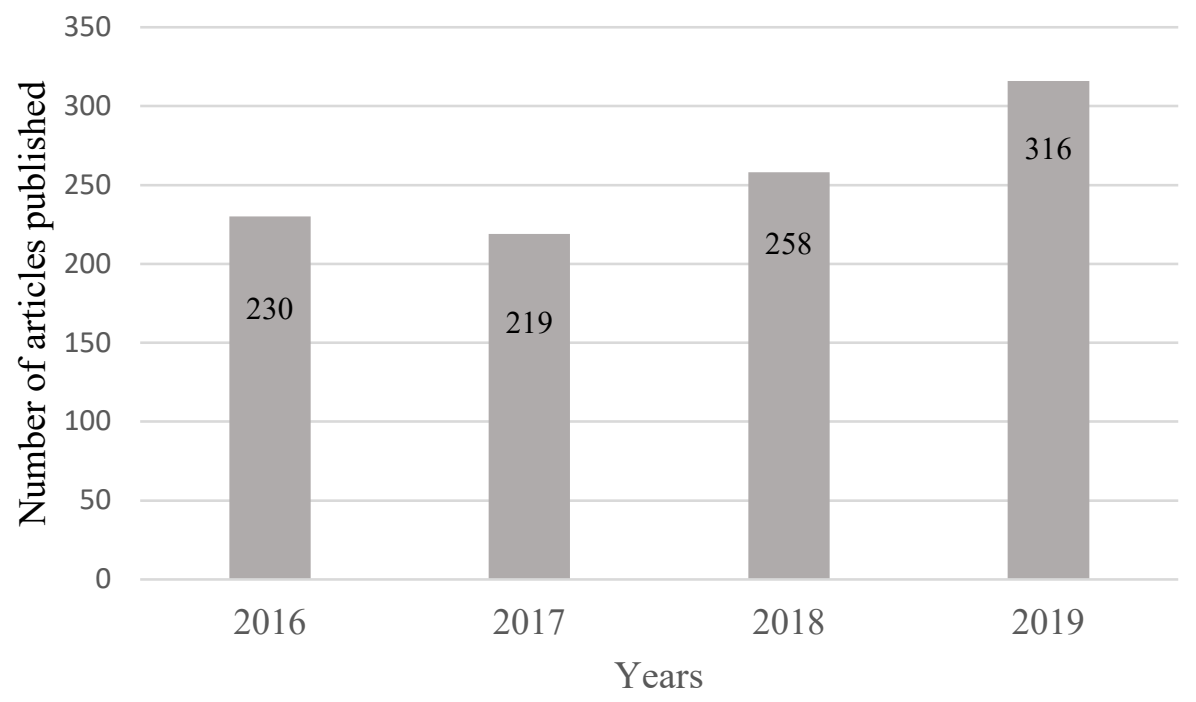

Figure 3. Distribution of studies by publication year.

\section{Discussion}

The most used research model in the studies analyzed was the quantitative method. The most common dependent variable in the studies is learning outcomes. The quantitative studies we examined generally addressed the learning outcomes through pre-tests and post-tests. Wu et al.'s (2012) meta-analysis study, in which they examined trends in m-learning studies between 2003 and 2010, also concluded that quantitative studies were more preferred than qualitative studies. In some of the studies, we identified the links and trends between variables related to the sample. The most commonly used test technique (Orhan, 2018) in the articles was descriptive analysis (22.28\%). When we review all the articles, the most-studied variables were earning outcomes (20.24\%), attitude (8.43\%) and motivation (5.22\%). We investigated these variables using experimental design. Variable types examined in this direction may have affected this finding. With regard to these variables, quantitative estimates were preferred in the studies (Miyata \& Kai, 2009). In the study by Zawacki-Richter, Bäcker, and Vogt (2009), which examined m-learning studies between 2000 and 2008, the authors found that quantitative studies were the majority. The study of Bozkurt et al. (2015), which examined dissertations between 1986 and 2014, concluded that the quantitative method was the most preferred. In other research on recent m-learning studies, the most preferred method found has been quantitative studies (Kavaklı \& Yakın, 2019; Zengin, Şengel, \& Özdemir, 2018; Chee et al., 2017).

When we analyzed the studies in terms of sample size, we found the most preferred size to be between 31 and 300. The literature (Kavaklı \& Yakın, 2019; Korucu \& Biçer, 2019), has found that most studies on m-learning have been carried out within this sample size. When the studies are analyzed in terms of sample level in this study, the most studies preferred a level of higher education. The study by Wu et al. (2012) found that the majority of studies that used the level focused on a higher education level. Similarly, Bozkurt et al. (2015) concluded that higher education students were the preferred level for samples. In other studies as well, the preferred sample level has been higher education (Açıkgül, 2019; Padmo, Idrus, \& Ardiassih, 2019; Kavaklı \& Yakın, 2019). Easier access to higher education students 
may have caused this finding. In the context of higher education, the number of students in classes is over 30 .

Learning fields of the studies differed. We found that $22.68 \%$ of the studies were in the field of social sciences, $18.18 \%$ in humanities, and $14.37 \%$ in natural sciences. We found that the studies are concentrated in the fields of social sciences and the humanities. Wu et al. (2012) also observed that social sciences and the humanities are the most studied learning field. Studies have been done in the field of education. Students' experiences and behaviors and learners' interactions with applications have been examined. These conclusions support our findings that social sciences and the humanities were the preferred fields.

Within the scope of this study, we examined the subject areas of the articles and determined that the majority of the studies were focused on technology. Sub-areas - such as the impact of tools and equipment, the role of these tools in learning, students' familiarity with the tools, especially in technology - were among the most discussed topics, which is similar to findings in Wu et al. (2012). In many studies, m-learning is integrated into education and used as a tool or for some specific purpose. In this case, our finding that the majority subject area is technology was expected.

We observed that the questionnaire was used to collect data in the clear majority of the articles within the scope of the study. This result supports studies carried out by Wu et al. (2012) and Chee et al. (2017). Data collection tools-such as question design, self-managed questionnaire, mail survey, question types, question statement, structure of the questionnaire, and Web-based questionnaire-are generally combined within the category of the questionnaire.

When we examined the data analysis techniques of the studies, we found that the descriptive analysis is the most used technique. We determined that studies whose second place is not expressed with data, statistical data are not needed and not available.

Learning outcomes include test results and end of the year degrees used in cognitive performance measurements, academic achievement, and knowledge acquisition. Similarly, the dependent variable, which was also handled by Lai (2020), showed a majority in academic achievement.

The determining factor among those affecting the choice of technological devices used in learning environments, besides suitability for the purpose and student needs, may be that they are the most widely used tools of their period. In this sense, literature reviews are very useful in revealing technology trends. Chee et al. (2017) also state that customer preferences in the mobile technology market affect the type of device selected to use in m-learning research. This study found that the most used mobile device type is the smartphone, and that tablets take second place. These results overlap with different study results in the literature (Baran, 2014; Chee et al., 2017; Crompton, Burke \& Gregory, 2017; Hwang \& Wu, 2014; Kaliisa \& Picard, 2017; Wu et al., 2012). However, contrary to the results of our study showing PDAs to be the least preferred mobile devices, literature reviews have found that PDAs are the second most used mobile device (Crompton et al., 2017; Hwang \& Wu, 2014; Wu et al., 2012). This difference may be due to the fact that the articles examined in this study are more current. 


\section{Conclusion}

Studies that reveal the effectiveness of a learning or teaching method often share their data on the results achieved by learners who use this method, such as success, attitude, and satisfaction. In particular, the primary aim of students that continue their education activities within the scope of formal education is to increase academic achievement. Within the scope of m-learning research, the literature indicates that the most discussed dependent variable in the studies is the learning outcome. The dimensions examined in the analyzed studies were effective in assisting the selection of the quantitative estimates for this study. There are few studies using qualitative methods to examine the behaviors of learners with mlearning. This study of m-learning issues forms an important reference for future research in m-learning by adding to the limited existing research.

\section{Suggestions}

Regarding the distribution of the studies, recent and previous studies show similar findings to ours, evidence of the continuing trend in m-learning. However, the studies differ in research models, sample sizes, sample levels, learning field, data collection tools and techniques, and dependent and independent variables. On the other hand, we found that the studies in the field of m-learning are usually quantitative or are literature reviews. In future studies, the effectiveness, usability and message design of m-learning applications can be examined using qualitative methods. In addition, in the scope of mobile applications, the literature can be enriched with qualitative research that investigates metaphor studies and misconceptions. 


\section{References}

Açlkgül, K. (2019). Investigation of pre-service mathematics teachers' mobile learning readiness levels. Educational Technology Theory and Practice, 9(2), 566-587. doi: 10.17943/etku.566739

Al-Adwan, A. S., Al-Madadha, A., \& Zvirzdinaite, Z. (2018). Modeling students' readiness to adopt mobile learning in higher education: An empirical study. International Review of Research in Open and Distributed Learning, 19(1). doi: 10.19173/irrodl.v19i1.3256

Alkhezzi, F., \& Al-Dousari, W. (2016). The impact of mobile learning on ESP learners' performance. Journal of Educators Online, 13(2), 73-101. Retrieved from https://files.eric.ed.gov/fulltext/EJ1106736.pdf

Baran, E. (2014). A review of research on mobile learning in teacher education. Journal of Educational Technology \& Society, 17(4), 17-32. Retrieved from https://www.jstor.org/stable/10.2307/jeductechsoci.17.4.17

Beissel-Durrant, G. (2004). A typology of research methods within the social sciences (NCRM Working Paper). Southampton, UK: ESRC National Centre for Research Methods and Southampton Statistical Sciences Research Institute. Retrieved from http://eprints.ncrm.ac.uk/115/1/NCRMResearchMethodsTypology.pdf

Bozkurt, A., Kumtepe, E. G., Kumtepe, A. T., Aydın, İ. E., Bozkaya, M., \& Aydın, C. H. (2015). Research trends in Turkish distance education: A content analysis of dissertations, 1986-2014. European Journal of Open Distance and E-learning, 18(2), 1-21. doi: 10.1515/eurodl-2015$\underline{0010}$

Brown, J. S., Collins, A., \& Duguid, P. (1989). Situated cognition and the culture of learning. Educational Researcher, 18(1), 32-42. doi: 10.3102/0013189X018001032

Chase, T. J., Julius, A., Chandan, J. S., Powell, E., Hall, C. S., Phillips, B. L., \& Fernando, B. (2018). Mobile learning in medicine: An evaluation of attitudes and behaviours of medical students. BMC Medical Education, 18(152). doi: 10.1186/s12909-018-1264-5

Chee, K. N., Yahaya, N., İbrahim, N. H., \& Hasan, M. N. (2017). Review of mobile learning trends 2010-2015: A meta-analysis. Journal of Educational Technology \& Society, 2O(2), 113-126. Retrieved from https://www.jstor.org/stable/10.2307/90002168

Chinnery, G. M. (2006). Emerging technologies: Going to the MALL: Mobile assisted language learning. Language Learning \& Technology, 1O(1), 9-16. Retrieved from http://llt.msu.edu/volionum1/emerging/

Cohen, A., \& Ezra, O. (2018). Development of a contextualised MALL research framework based on L2 Chinese empirical study. Computer Assisted Language Learning, 31(7), 764-789. doi: $\underline{10.1080 / 09588221.2018 .1449756}$

Crompton, H., Burke, D., \& Gregory, K. H. (2017). The use of mobile learning in PK-12 education: A systematic review. Computers \& Education, 11O, 51-63. doi: 10.1016/j.compedu.2017.03.013 
Drysdale, J. S., Graham, C. R., Spring, K. J., \& Halverson, L. R. (2013). An analysis of research trends in dissertations and theses studying blended learning. The Internet and Higher Education, 17, 90-100. doi: 10.1016/j.iheduc.2012.11.003

Göktaş, Y., Küçük, S., Aydemir, M., Telli, E., Arpacık, O., Yıldırım, G., \& Reisoğlu, I. (2012). Educational technology research trends in Turkey: A content analysis of the 2000-2009 decade. Educational Sciences: Theory and Practice, 12(1), 191-199. Retrieved from https://files.eric.ed.gov/fulltext/EJ978439.pdf

Huang, C. S., Yang, S. J., Chiang, T. H., \& Su, A. Y. (2016). Effects of situated mobile learning approach on learning motivation and performance of EFL students. Journal of Educational Technology \& Society, 19(1), 263-276. Retrieved from https://www.jstor.org/stable/10.2307/jeductechsoci.19.1.263

Hung, H.-C., Shwu-Ching Young, S., \& Lin, K.-C. (2018). Exploring the effects of integrating the iPad to improve students' motivation and badminton skills: A WISER model for physical education. Technology, Pedagogy and Education, 27(3), 265-278. doi: 10.1080/1475939X.2017.1384756

Hung, J. L., \& Zhang, K. (2012). Examining mobile learning trends 2003-2008: A categorical metatrend analysis using text mining techniques. Journal of Computing in Higher Education, 24(1), 1-17. doi: 10.1007/s12528-011-9044-9

Hwang, G.-J., \& Wu, P.-H. (2014). Applications, impacts and trends of mobile technology-enhanced learning: A review of 2008-2012 publications in selected SSCI journals. International Journal of Mobile Learning and Organisation, 8(2), 83-95. doi: 10.1504/IJMLO.2014.062346

Judge, S., Floyd, K., \& Jeffs, T. (2015). Using mobile media devices and apps to promote young children's learning. Young children and families in the information age (pp. 117-131). Dordrecht: Springer. doi: 10.1007/978-94-017-9184-7 7

Kagan. J. (2009). The three cultures: Natural sciences, social sciences and the humanities in the 21st century. Cambridge, UK: Cambridge University Press. Retrieved from https://pdfs.semanticscholar.org/209a/f75d6223719496a2c7cd767552e5e3303604.pdf

Kaliisa, R., \& Picard, M. (2017). A systematic review on mobile learning in higher education: The African perspective. Turkish Online Journal of Educational Technology, 16(1), 1-18. Retrieved from https://files.eric.ed.gov/fulltext/EJ1124918.pdf

Karanfiller, T., Yurtkan, K., Rüştüoğlu, O., \& Göksu, H. (2018). Effect of mobile teaching on students who need special education. Quality \& Quantity, 52(2), 1353-1363. doi: 10.1007/s11135-018$\underline{0715-8}$

Karataş, S., Özcan, S., Polat, E., Yllmaz, Y., \& Topuz, A.C. (2014). Trends in distance education: Theories \& methods, In T. V. Yuzer and G. Eby (Eds.), Emerging priorities and trends in distance education: Communication, pedagogy, and technology (pp. 141-155). Hershey, PA: Information Science Reference. IGI Global. doi: 10.4018/978-1-4666-5162-3.cho10 
Karataş, S., Yılmaz, A. B., Dikmen, C. H., Ermiş, U. F., \& Gürbüz, O. (2017). Interaction in distance education environments: A Trend Analysis. Quarterly Review of Distance Education, 18(1), 63-82. Retrieved from https://books.google.com.tr/books?hl=en\&lr=\&id=Qdg1DwAAQBAJ\&oi=fnd\&pg=PA63\&ots= 9RentDMfhG\&sig=gQh5xAv-1hDspjD89rV8xYbkt9w\&redir_esc $=\mathrm{y} \# \mathrm{v}=$ onepage\&q\&f=false

Kavaklı, A., \& Yakın, İ., (2019). Mobil learning: A content analysis of publications from 2015-2019. The Black Sea Journal of Social Sciences, 11(21), 251-268. Retrieved from https://dergipark.org.tr/en/download/article-file/898126

Kılıç, S. (2015). Kappa test. Journal of Mood Disorders, 5(3). Retrieved from http://pbsciences.org/pdf/TR-JMOOD-ofco3dbc.pdf

Klímová, B. (2018). Mobile phones and/or smartphones and their apps for teaching English as a foreign language. Education and Information Technologies, 23(3), 1091-1099. doi: $\underline{10.1007 / \mathrm{s} 10639-017-9655-5}$

Korucu, A. T., \& Biçer, H. (2019). Mobile learning: A content analysis for 2010-2017 National Studies. Trakya Journal of Education, 9(1), 32-43. doi: 10.24315/tred.516911

Lai, C. L. (2020). Trends of mobile learning: A review of the top 100 highly cited papers. British Journal of Educational Technology, 51(3), 721-742. doi: 10.1111/bjet.12884

Laurillard, D. (2007). Pedagogical forms of mobile learning: Framing research questions. In N. Pachler (Ed.), Mobile learning: Towards a research agenda (pp. 153-175). London: WLE Centre, IoE. Retrieved from https://discovery.ucl.ac.uk/id/eprint/10000627/1/Mobile C6 Laurillard.pdf

Lin, Y.-T., \& Lin, Y.-C. (2016). Effects of mental process integrated nursing training using mobile device on students' cognitive load, learning attitudes, acceptance, and achievements. Computers in Human Behavior, 55, 1213-1221. doi: 10.1016/j.chb.2015.03.076

OECD. (2007). Revised field of science and technology (FOS) classification in the frascati manual. Directorate for Science, Technology and Industry Committee for Scientific and Technological Policy. Retrieved from http://www.oecd.org/sti/inno/38235147.pdf

McQuiggan, S., Kosturko, L., McQuiggan, J., \& Sabourin, J. (2015). Mobile learning: A handbook for developers, educators, and learners: John Wiley \& Sons. SAS Institute Inc doi: $\underline{10.1002 / 9781118938942}$

Miyata, H., \& Kai, I. (2009). Reconsidering evaluation criteria for scientific adequacy in health care research: An integrative framework of quantitative and qualitative criteria. International Journal of Qualitative Methods, 8(1), 64-75. doi: 10.1177/160940690900800106

Nerminathan, A., Harrison, A., Phelps, M., Scott, K. M., \& Alexander, S. (2017). Doctors' use of mobile devices in the clinical setting: A mixed methods study. Internal Medicine Journal, 47(3), 291298. doi: $10.1111 /$ imj.13349 
Orhan, U. (2018). Evaluating the reflection of quantitative and qualitative research designs in management studies and the ignorance of the qualitative design by the positivist tradition. The Journal of Academic Social Science Studies, 72, 433-445. doi: 10.9761/JASSS7843

Özdaml, F., \& Çavuş, N. (2011). Basic elements and characteristics of mobile learning. ProcediaSocial and Behavioral Sciences, 28, 937-942. doi: 10.1016/j.sbspro.2011.11.173

Padmo, D., Idrus, O., \& Ardiasih, L. S. (2019). The utilization of mobile devices for improving access to online learning for distance education's students. Turkish Online Journal of Educational Technology, 2o(2), 147-161. doi: 10.17718/tojde.557858

Perry, D. (2003). Handheld computers (PDAs) in schools. Coventry, UK: British Educational Communications and Technology Agency (Becta). Retrieved from https://dera.ioe.ac.uk/1644/7/becta 2003 handhelds report Redacted.pdf

Sharples, M., Arnedillo-Sánchez, I., Milrad, M., \& Vavoula, G. (2009). Mobile learning. In N. Balacheff, S. Ludvigsen, T. de Jong, A. Lazonder, \& S. Barnes (Eds.), Technology-Enhanced Learning (pp. 233-249). Dordrecht: Springer. doi: 10.1007/978-1-4020-9827-7 14

Song, Y., Wong, L.-H., \& Looi, C.-K. (2012). Fostering personalized learning in science inquiry supported by mobile technologies. Educational Technology Research and Development, 6o(4), 679-701. doi: 10.1007/s11423-012-924.5-6

Sönmez, A, Göçmez, L, Uygun, D. \& Ataizi, M. (2018). A review of current studies of mobile learning. Journal of Educational Technology and Online Learning, 1(1), 12-27. doi: 10.31681/jetol.378241

Towobola, W. L., \& Raimi, L. (2011). Open distance learning (ODL): A catalyst for educational and entrepreneurship development in Nigeria. Continental Journal of Education Research, 4(3), 1-11. Retrieved from https://www.academia.edu/3859655

Wu, W.-H., Wu, Y.-C. J., Chen, C.-Y., Kao, H.-Y., Lin, C.-H., \& Huang, S.-H. (2012). Review of trends from mobile learning studies: A meta-analysis. Computers \& Education, 59(2), 817-827. doi: 10.1016/j.compedu.2012.03.016

Yıldırım, A., \& Şimşek, H. (2018). Qualitative research methods in the social sciences (11 ${ }^{\text {th }}$ ed.). Ankara: Seçkin Publications. Retrieved from https://www.seckin.com.tr/kitap/991264765

Yüksekdağ, B. B. (2016). Learning in open and distance education. Journal of Open Education Practices and Research, 2(4), 127-138. Retrieved from http://auad.anadolu.edu.tr/yonetim/icerik/makaleler/195-published.pdf

Zawacki-Richter, O., Baecker, E. M., \& Vogt, S. (2009). Review of distance education research (2000 to 2008): Analysis of research areas, methods, and authorship patterns. The International Review of Research in Open and Distributed Learning, 10(6), 21-50. 10.19173/irrodl.v10i6.741 
Zengin, M., Şengel, E., \& Özdemir, M. A. (2018). Research trends in mobile learning in education. Instructional Technologies and Teacher Education Journal, 7(1), 18-35. Retrieved from https://dergipark.org.tr/en/download/article-file/464086

\section{Athabasca}

University

(c) 